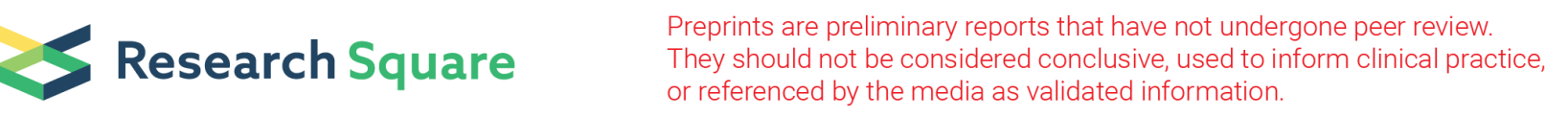

\title{
An Analysis of Mangrove Forest Damage Due to Illegal Logging and Its Effect on Carbon Stock and Absorption in East Java, Indonesia
}

Rudianto Rudianto ( $\sim$ rudiantoita@gmail.com )

Universitas Brawijaya Fakultas Perikanan dan Ilmu Kelautan https://orcid.org/0000-0003-2636-2790

Dietrich G Bengen

Institut Pertanian Bogor

\section{Research}

Keywords: Mangrove, carbon, land change, land conversion, illegal logging, East Java, Indonesia

Posted Date: September 24th, 2020

DOI: https://doi.org/10.21203/rs.3.rs-64373/v1

License: (c) (i) This work is licensed under a Creative Commons Attribution 4.0 International License.

Read Full License 


\section{Abstract}

\section{Background}

Mangroves are extraordinary forests. They can protect the beach preventing soil erosion, and absorb and store carbon dioxide. Therefore, mangrove forests help decrease the concentration of carbon dioxide and a greenhouse gas in the atmosphere [1]. Mangroves are very efficient carbon sinks and store it in large quantities in the form of biomass and sediments for a long time [2]. The destruction of mangrove forests occurs because of the increasingly intensive land changes for the construction of settlements in coastal areas for both low-income and high-income populations. Also, the in-optimal management of mangrove forests by the government and the community leads to their damage. It means, the management system being implemented is not in tune with scientific findings.

Results

The destruction of mangrove forests in East Java has occurred due to the intensification of land conversion. Accordingly, the average carbon sequestration and storage by mangroves in East Java can be classified as moderate to low. Illegal logging is the leading cause, so there needs to be a clear policy that involves the government and the community.

Conclusion

A strategy formulation to prevent illegal logging and increase carbon sequestration and storage has to be carried out in such a way that those responsible for the damage also compensate for it. Every community member must participate in the decision-making processes and the protection and management of mangrove forests.

\section{Background}

Mangroves, as a coastal ecosystem found in tropical and subtropical areas, store carbon. In the last few decades, mangroves have experienced an increasingly rapid rate of loss due to changes in land use. Habitat conversion changes vary globally. The causes of habitat conversion changes include conversion to cultivated areas, expansion of agriculture, over-exploitation of forests, construction of industries and upstream dams, dredging, eutrophication of overlying water, and urban development [3]. Chen et al. [4] state that the carbon in these wetland soils is buried for thousands of years and does not reach saturation. This kind of carbon is different from the carbon present in freshwater systems and generally does not produce much methane gas.

Coastal carbon is trapped by sediment and plays an essential ecological role, including carrying limited nutrients [5], and helping coastal habitats adapt to sea-level rise [6]. Thus, coastal areas are a strategic route to capture and store carbon [7]. The depletion of mangrove cover decreases the ability of 
mangroves to store and absorb mangroves. Logging of mangroves for various purposes, both licensed and unlicensed, is a form of illegal logging from an ecological perspective [8].

Indonesia has mangrove biodiversity, representing around $22.6 \%$ of the world's total mangrove ecosystems [9]. Therefore, Indonesia is a country with the most extensive mangrove forests in the world [10]. Mangrove forests are ecological systems in coastal and estuarine areas that receive nutrients and sediment from terrestrial environments, but deforestation and mangrove degradation continue [9, 11-14]. Supposedly, the mangrove biodiversity is not managed correctly. In that case, it will soon only become a part of history [15]. Rahadian et al. [16] reported the diversity of mangrove area data is a national problem given the importance of historical data on the existence of reliable and consistent mangrove forests. The reliability of historical data on mangrove forests is essential for monitoring and supporting the development of mangrove management strategies.

Indonesia has lost mangrove forests about 600,000 ha for shrimp farms [17]. Mangrove area reduction also occurs in the East Java province, although there are variations in data from several existing sources. This condition is very confusing [16]. Silvius et al. [18] reported that the mangrove forest was recorded as 5000 ha in the 1960s; however, in 1987, it was decreased by 500 ha. . Burbridge, Koesoebiono [19] stated that the area of mangrove forest in East Java in 1982 was 6000 ha, equal to the mangrove forest area in 1978, although the interval was four years. Soegiarto, Sukardjo [20] confirmed the area of mangrove forest in East Java was the same as that in another research that covered an area of 6,000 ha [19]. RePPProT [21] reported that the mangrove forest area was 7,500 ha, which was relatively the same size as in the research done by Naamin [22] and Choong et al. [23]. The data presented by BIG [24] showed that the mangrove forest area was 18,253.82 ha, whereas the data by KLHK [25] showed that the mangrove forest covered $71,708.20 \mathrm{ha}$. The one map policy by Susanto et al. [26] stated that mangrove forest data in East Java covered 21,944 ha.

\section{Results And Discussion}

Mangrove forests in two locations in East Java Province were selected as the research setting. East Java Province was chosen because almost half of the mangrove forests had been damaged. Data by Susanto et al. [26] compared with data by Usmawati [27] show damaged mangrove from 61,700.20 ha in 2010 to 21,944 ha in 2017; this means that $35.6 \%$ of the mangrove forest in East Java was damaged within seven years.

Usmawati [27] demonstrated mangroves at the Clungup Beach absorb carbon biomass of 125.87 tons $\mathrm{ha}^{-1}$, and a litter of mangrove leaves can absorb $15.17 \mathrm{~kg} \mathrm{ha}^{-1}$ per month. Carbon in a mangrove leaf litter absorbs 0.25 tons ha ${ }^{-1}$ per month, while the carbon stock holds 50.71 tons ha-1. Research results of Fikri [28] on the natural mangrove forest of the Lamongan Regency indicated that the carbon stock was 40.66 $\mathrm{MgC} \mathrm{ha}{ }^{-1}$. Rizky [29] showed that the estimated carbon stock in mangrove vegetation in Alas Purwo National Park in Banyuwangi Regency was 2,711 tons ha- ${ }^{-1}$, with an average carbon stock $157.5 \mathrm{~kg}$ per tree. Research by Aldus [30] on carbon stock and carbon dioxide absorption in Penunggul Village, 
Pasuruan Regency, stated that the total estimated amount was $501.99 \mathrm{MgC} \mathrm{ha}^{-1}$ with a carbon dioxide absorption of 1,840.63 MgC ha-1. Also, Research by Adam [31] on the Coast of Lamongan Regency identified 251,307 tons per ha-1. These results are different from the results of Rizky [29], which show that the estimated total carbon stock in the coastal area of the Lamongan Regency is 181.3 tons $\mathrm{C} \mathrm{Ha}^{-1}$, and the total absorption is 374.1 tons $\mathrm{C}$ ha $^{-1}$. Based on measurements conducted by Kauffman et al. [32], measurements in Kalimantan carbon stock are 1,259 MgC ha-1. Based on this description, the average carbon sequestration and storage in East Java can be classified as moderate to low. The low carbon sequestration and storage in mangrove forests are mainly due to illegal logging that causes deforestation $[8,33]$.

Before conducting Analytical Hierarchy Process (AHP) and Partial Least Square (PLS) analyses, respondents in local government, society, and the private sector were surveyed. The table 1 shows the types of respondents interviewed.

\section{Table 1 Types of respondents}

\begin{tabular}{|llllll|}
\hline No. & Type of Respondents & CCO & LCO & APP & PVP \\
\hline 1. & Local Governments & 5 & 5 & 5 & 5 \\
\hline 2. & Local People & 5 & 5 & 5 & 5 \\
\hline 3. & Private Sectors & 5 & 5 & 5 & 5 \\
\hline 4. & Fishermen & 8 & 8 & 8 & 8 \\
\hline 5. & NGO & 7 & 7 & 7 & 7 \\
& Total Respondents & 30 & 30 & 30 & 30 \\
\hline
\end{tabular}

Note: $\mathrm{NGO}=$ non-government organizations; $\mathrm{CCM}=$ Clungup Coastal, Malang Regency; $\mathrm{CLR}=$ Coastal of Lamongan Regency; APP = Alas Purwo National Park; PVP = Penunggal Village, Pasuruan Regency.

There are five facets to be examined using the AHP method: irrational use, illegal logging, weak carbon sequestration, and the effect of forest damage on both carbon sequestration and law enforcement. They are stated as follows:

The first objective is to identify public opinion on irrational use (Fig. 2). The test using AHP obtained the value of 0.190 for the alternative "community does not care about the destruction of mangrove forests." This is the basis for proposing that illegal logging causes deforestation due to the accessibility of reaching mangrove forests. Accessibility means treating everyone the same concerning the use of mangrove forests and giving them equal opportunities.

Objective 2 is to learn people's opinions on illegal logging (Fig. 3). The AHP test found the most popular option was "Residential areas increasingly diminish mangrove forests" with a value of 0.248. 
Objective 3 is to identify public opinion on the effect of forest damage on carbon sequestration (Fig. 4). The AHP test found the most popular option was "Management of mangrove forests is not optimal" with a value of 0.206 .

Objective 4 is to identify public opinion on law enforcement. The AHP test found the most popular option was "Law enforcement should have limited human resources" with a value of 0.316 .

Objective 5 is to identify public opinion on weak carbon sequestration. The AHP test found the most popular option was "Lack of synergy between the government and the community" with a value of 0.316 .

The formulation of AHP is as follows:

1. The community does not care about the destruction of mangrove forests.

2. Residential areas increasingly diminish mangrove forests.

3. Management of mangrove forests is not optimal.

4. The community favours limited human resources for law enforcement.

5. There is a lack of synergy between the government and the community.

Furthermore, the results of the PLS method are as follows. Outer model testing is conducted by testing convergent validity, discriminant validity, and reliability of each observed research variable.

Table 2: Convergent validity results 


\begin{tabular}{|c|c|c|c|c|c|}
\hline & $\begin{array}{l}\text { Original Sample } \\
(0)\end{array}$ & $\begin{array}{l}\text { Standard Error } \\
\text { (STERR) }\end{array}$ & $\begin{array}{l}\text { T Statistics } \\
\text { (O/STERR) }\end{array}$ & $\begin{array}{l}\mathrm{P}- \\
\text { value }\end{array}$ & Remarks \\
\hline $\begin{array}{l}X 1.1<- \\
X 1\end{array}$ & 0.818 & 0.018 & 46.457 & 0.000 & Valid \\
\hline $\begin{array}{l}\mathrm{X} 1.2<- \\
\mathrm{X} 1\end{array}$ & 0.571 & 0.030 & 18.868 & 0.000 & Valid \\
\hline $\begin{array}{l}X 1.4<- \\
X 1\end{array}$ & 0.841 & 0.008 & 100.795 & 0.000 & Valid \\
\hline $\begin{array}{l}X 1.6<- \\
X 1\end{array}$ & 0.763 & 0.018 & 42.154 & 0.000 & Valid \\
\hline $\begin{array}{l}X 1.7<- \\
X 1\end{array}$ & 0.818 & 0.018 & 46.457 & 0.000 & Valid \\
\hline $\begin{array}{l}X 2.1<- \\
X 2\end{array}$ & 0.681 & 0.030 & 22.578 & 0.000 & Valid \\
\hline $\begin{array}{l}X 2.3<- \\
X 2\end{array}$ & 0.945 & 0.004 & 241.598 & 0.000 & Valid \\
\hline $\begin{array}{l}X 2.7<- \\
X 2\end{array}$ & 0.677 & 0.026 & 26.079 & 0.000 & Valid \\
\hline $\begin{array}{l}\text { X3.2<- } \\
\text { X3 }\end{array}$ & 0.945 & 0.003 & 372.005 & 0.000 & Valid \\
\hline $\begin{array}{l}X 3.4<- \\
\text { X3 }\end{array}$ & 0.945 & 0.003 & 372.005 & 0.000 & Valid \\
\hline $\begin{array}{l}X 3.6<- \\
X 3\end{array}$ & 0.583 & 0.029 & 19.884 & 0.000 & Valid \\
\hline $\begin{array}{l}X 3.7<- \\
X 3\end{array}$ & 0.775 & 0.022 & 36.018 & 0.000 & Valid \\
\hline $\begin{array}{l}X 4.2<- \\
X 4\end{array}$ & 0.980 & 0.001 & 1062.247 & 0.000 & Valid \\
\hline $\begin{array}{l}X 4.4<- \\
X 4\end{array}$ & 0.980 & 0.001 & 1062.247 & 0.000 & Valid \\
\hline $\begin{array}{l}X 4.5<- \\
X 4\end{array}$ & 0.728 & 0.032 & 22.770 & 0.000 & Valid \\
\hline $\begin{array}{l}X 5.2<- \\
X 5\end{array}$ & 0.930 & 0.006 & 154.808 & 0.000 & Valid \\
\hline $\begin{array}{l}X 5.3<- \\
X 5\end{array}$ & 0.688 & 0.022 & 30.944 & 0.000 & Valid \\
\hline $\begin{array}{l}X 5.4<- \\
X 5\end{array}$ & 0.686 & 0.022 & 31.376 & 0.000 & Valid \\
\hline
\end{tabular}


A convergent validity test on objective 1, "Irrational use," obtained four valid indicators from the seven initial indicators used. The valid indicators are indicator X1.1, "Community utilizes mangrove forests for daily living needs", indicator X1.2, "Community does not have awareness about the functions and roles of mangroves", indicator X1.4, "Community access to mangrove forests is easily achieved", and indicator $\mathrm{X} 1.6$, "There is no supervision from the stakeholders." These four indicators meet the convergent validity test requirements, which have a factor loading value of more than 0.5 .

The convergent validity test on objective 2, namely "Illegal logging", identified three valid indicators out of the seven initial indicators used. Valid indicators are indicator X2.1, "People steal mangrove wood as it has a high sale value", indicator X2.3, "Declining mangrove forests are used for agriculture, plantations, and animal husbandry", and indicator X2.7, "The area of mangrove forests is increasingly reduced to be used for aquaculture." These three indicators meet the convergent validity test requirements, which have a factor loading value of more than 0.5 . The convergent validity test on objective 3, namely "Effect of forest damage on carbon sequestration", obtained four valid indicators from the seven initial indicators used. The valid indicators are indicator X3.2, "Absorption of mangrove forests has weakened", indicator X3.4, "Above-ground biomass (stems, branches, twigs, leaves, flowers, and fruit) absorption is weak", indicator X3.6, "The tree diameter is getting smaller due to the storage of biomass from the conversion of carbon dioxide $\left(\mathrm{CO}_{2}\right)$, which is getting smaller in line with the less $\mathrm{CO}_{2}$ absorbed by the mangrove tree", and indicator X3.7, "Mangrove conservation efforts are not optimal." These four indicators meet the convergent validity test requirements, which have a factor loading value of more than 0.5 .

The convergent validity test on objective 4, namely "Weak carbon sequestration", identified three valid indicators out of the five initial indicators used. Valid indicators are indicator X4.2, "The conversion of mangrove land functions intensively", indicator X4.4, "Mangrove deforestation is intensive", and indicator X4.5, "Many mangrove trees are made into charcoal by residents." These three indicators meet the convergent validity test requirements, which have a factor loading value of more than 0.5 .

The convergent validity test results on goal five, namely "Law enforcement", obtained three valid indicators from the four initial indicators used. Valid indicators are indicator X5.2 "There are no clear legal sanctions", indicator X5.3 "Low community involvement", and indicator X5.4 "Limited number of human resources for law enforcement." These three indicators meet the convergent validity test requirements, which have a factor loading value of more than 0.5 .

\section{Table 3: The result of discriminant validity and constructive reliability}




\begin{tabular}{|llllllllll|}
\hline \multicolumn{4}{|c}{ Discriminant Validity } & & \multicolumn{3}{c|}{ Constructive Reliability } \\
\hline & $\begin{array}{l}\text { AVE } \\
\text { roots }\end{array}$ & $\mathbf{X 1}$ & $\mathbf{X 2}$ & $\mathbf{X 3}$ & $\mathbf{X 4}$ & $\mathbf{X 5}$ & $\begin{array}{l}\text { Composite } \\
\text { Reliability }\end{array}$ & $\begin{array}{l}\text { Cronbach's } \\
\text { Alpha }\end{array}$ \\
\hline $\mathbf{X 1}$ & 0.769 & 1.000 & 0.564 & 0.613 & 0.605 & 0.638 & 0.877 & 0.822 \\
\hline X2 & 0.778 & 0.563 & 1.000 & 0.686 & 0.659 & 0.667 & 0.817 & 0.652 \\
\hline X3 & 0.826 & 0.613 & 0.686 & 1.000 & 0.627 & 0.634 & 0.892 & 0.839 \\
\hline X4 & 0.904 & 0.605 & 0.659 & 0.627 & 1.000 & 0.618 & 0.929 & 0.884 \\
\hline X5 & 0.777 & 0.638 & 0.667 & 0.634 & 0.618 & 1.000 & 0.817 & 0.652 \\
\hline
\end{tabular}

The discriminant validity test results obtained by the root value of AVE from each latent variable or the destination variable are higher than the correlation between latent variables to meet the discriminant validity test requirements. The construct reliability test obtained the Composite Reliability value of each latent variable, which is more than 0.70 , and the Cronbach Alpha value of each latent variable is more than 0.60 , so it meets the construct reliability requirements.

Testing the inner model was done by testing the influence between latent variables. The results of the inner model and hypothesis testing are presented as follows:

1. The influence of variable X1, "Irrational use", on the $X 2$ variable, "Illegal logging", obtained a path coefficient of 0.963 with a significance value of $0.000(p<0.05)$. So, a significant positive effect was obtained. It means that the higher the respondent's perception of variable X1, namely "Irrational use" of mangrove forests, will significantly influence the respondent's perception of variable X2, namely "Illegal logging".

2. The influence of the $X 2$ variable, "Illegal logging", on the X3 variable, "Effect of forest damage on carbon sequestration", obtained a path coefficient of 0.986 with a significance value of $0.000(p$ $<0.05)$. So, a significant positive effect was obtained. It means that the higher the respondent's perception of variable X2, namely "Illegal logging", will significantly influence the respondents' perceptions of variable X3, namely "effect of forest damage on carbon sequestration".

3. The influence of variable X2, "Illegal logging", on variable X5, "Law enforcement", obtained a path coefficient of 0.963 with a significance value of $0.000(p<0.05)$. So, a significant positive effect was obtained. It means that the higher the respondent's perception of the X2 variable, namely "Illegal logging", will significantly influence the respondent's perception of the variable X5 "Law enforcement".

4. The influence of the $X 3$ variable, "Effect of forest damage on carbon sequestration", on X4 variable, "Weak carbon sequestration", obtained a path coefficient of 0.963 with a significance value of 0.000 $(p<0.05)$. So, a significant positive effect was obtained. It means that the higher the respondent is on the $\mathrm{X} 3$ variable, namely "Effect of forest damage on carbon sequestration," will significantly affect the respondent's perception of the X4, namely "Weak carbon sequestration". 
Table 5 Inner model results and hypothesis testing

\begin{tabular}{|c|c|c|c|c|c|}
\hline & $\begin{array}{l}\text { Original Sample } \\
(0)\end{array}$ & $\begin{array}{l}\text { Standard Error } \\
\text { (STERR) }\end{array}$ & $\begin{array}{l}\text { T Statistics } \\
\text { (O/STERR) }\end{array}$ & $\begin{array}{l}\mathrm{P}- \\
\text { value }\end{array}$ & Remarks \\
\hline $\begin{array}{l}X 1-> \\
X 2\end{array}$ & 0.963 & 0.003 & 347.960 & 0.000 & Significant \\
\hline $\begin{array}{l}X 2 \\
X 3\end{array}$ & 0.986 & 0.001 & 1272.164 & 0.000 & Significant \\
\hline $\begin{array}{l}X 2-> \\
X 5\end{array}$ & 0.867 & 0.012 & 70.959 & 0.000 & Significant \\
\hline $\begin{array}{l}\text { X3 -> } \\
\text { X4 }\end{array}$ & 0.927 & 0.002 & 424.362 & 0.000 & Significant \\
\hline
\end{tabular}

The constructed model generating an essential point that irrational use means illegal logging (Fig. 7). The respondents' perception indicated that illegal logging creates irrational activities with no permission, and sometimes the people can exploit mangroves every time they have an opportunity without government supervision. The respondents also mentioned that illegal logging leads to forest damage, which works against carbon sequestration. Data from mangroves' carbon sequestration and stock show that people will suffer from global warming, and there will be no protection from tsunamis. The presence of illegal logging suggests that law enforcement is weak, and forest damage will lead to weak carbon sequestration.

Irrational use 'will significantly affect the higher respondents' perceptions of the $\mathrm{X} 2$ variable "Illegal logging". Fig. 7 above shows the relationship between the five objectives and the relevance of each variable.

\section{Conclusion}

Following the mandate of Law Number 32 of 2009, it is necessary to take measures to protect and manage the environment to realise a healthy living environment. According to Article 28 of the 1945 Constitution of the Republic of Indonesia, a healthy environment is the right of every citizen. A strategy to prevent illegal logging and increase carbon sequestration and storage efforts is to be carried out as follows:

1. The state has the responsibility to guarantee citizens' rights to a healthy environment. With their authority, states must prevent the illegal logging of mangroves and all other activities that may destroy mangrove forests in the coastal environment.

2. Utilisation and management of natural resources must adhere to the principle of sustainable development. Thus, every citizen has the responsibility to preserve mangrove forests, including those 
responsible for future generations.

3. Utilisation and management techniques for mangrove forests must pay attention to various aspects, including economic, socio-cultural, and bio-geophysical characteristics.

4. The principle of polluting pay must be applied. That means that every person in charge of a business or individuals who cause pollution or damage to mangrove forests must pay a fine.

5. Every community member must participate in decision-making processes and the protection and management of mangrove forests.

\section{Methods}

As stated by Heriyanto, Subiandono [34], mangrove ecosystems, like other forest ecosystems, have an essential role as absorbers (sinks) of $\mathrm{CO}_{2}$ from the air. Thus mangrove forests have an essential role in stabilizing the climate, which is currently experiencing changes. The anthropogenic destruction of mangrove forests, especially through illegal logging, needs to be formulated using the AHP and PLS models. The argument is that the AHP and PLS methods should find illegal logging, including the best solution. The PLS method is a multivariate statistical technique that can handle many response variables and explanatory variables. This analysis is a better method of multiple regression analysis and principal component regression because this method is more robust or invulnerable. Meanwhile, the AHP is used to formulate a sustainable mangrove forest management policy to increase carbon sequestration and stock. As stated by Murray et al. [35], to increase the ability of mangrove vegetation to absorb and maintain a stable carbon stock, stakeholders need comprehensive efforts to increase the sequestration that eventually becomes buried in the soil.

\section{Abbreviations}

$$
\begin{aligned}
& \mathrm{AHP}=\text { Analytical Hierarchy Process } \\
& \mathrm{PLS}=\text { Partial Least Square } \\
& \mathrm{CCM}=\text { Clungup Coastal, Malang Regency } \\
& \mathrm{CLR}=\text { Coastal of Lamongan Regency } \\
& \mathrm{APP}=\text { Alas Purwo National Park } \\
& \mathrm{PVP}=\text { Penunggal Village, Pasuruan Regency } \\
& \mathrm{CO}_{2}=\text { carbon dioxide }
\end{aligned}
$$

\section{Declarations}

Availability of data and materials: Not applicable. 
Competing interests: The authors declare that they have no competing interests.

Funding: Not applicable.

\section{Authors' contributions:}

Conceptualization, Methodology, Investigation, Visualization, RR and DGB; Data curation, Writing-original draft, R; Supervision, Writing-review and Editing, DGB. All authors read and approved the final manuscript.

\section{Acknowledgements:}

We appreciate the support from the rectors, of both Brawijaya University and the IPB University, who allowed us to carry out collaborative research in research locations in East Java Province. We also appreciate our colleagues who took their time to review this article.

\section{Authors' information (optional):}

${ }^{1}$ Rudianto is a head of the research group on integrated coastal ecosystems restoration and sustainable development (ICESSMENT) in the Department of Fisheries Resources Utilization and Marine Sciences, Brawijaya University, Indonesia. ${ }^{2}$ Dietriech G. Bengen is a full professor at the Department of Marine Sciences and Technology, Faculty of Fisheries and Marine Sciences, IPB University, Indonesia. He focuses in marine and coastal ecology, environment and biodiversity, fisheries, small islands, ecotourism, integrated coastal management and sustainable management.

\section{References}

1. Huxham M, Whitlock D, Githaiga M, Dencer-Brown A. Carbon in the Coastal Seascape: How Interactions Between Mangrove Forests, Seagrass Meadows and Tidal Marshes Influence Carbon Storage. Current Forestry Reports. 2018;4(2):101-10. doi:10.1007/s40725-018-0077-4.

2. Yee SM. REDD and Blue Carbon: Carbon Payments for Mangrove Conservation. California: University of California; 2010.

3. Pendleton L, Donato DC, Murray BC, Crooks S, Jenkins WA, Sifleet S et al. Estimating global "blue carbon" emissions from conversion and degradation of vegetated coastal ecosystems. PLoS One. 2012;7(9):e43542. doi:10.1371/journal.pone.0043542.

4. Chen G, Chen B, Yu D, Tam NFY, Ye Y, Chen S. Soil greenhouse gas emissions reduce the contribution of mangrove plants to the atmospheric cooling effect. Environmental Research Letters. 2016;11(12). doi:10.1088/1748-9326/11/12/124019.

5. Kumara MP, Jayatissa LP, Krauss KW, Phillips DH, Huxham M. High mangrove density enhances surface accretion, surface elevation change, and tree survival in coastal areas susceptible to sealevel rise. Oecologia. 2010;164(2):545-53. doi:10.1007/s00442-010-1705-2. 
6. Krauss KW, McKee KL, Lovelock CE, Cahoon DR, Saintilan N, Reef R et al. How mangrove forests adjust to rising sea level. New Phytol. 2014;202(1):19-34. doi:10.1111/nph.12605.

7. Kennedy H, Beggins J, Duarte CM, Fourqurean JW, Holmer M, Marbà N et al. Seagrass sediments as a global carbon sink: Isotopic constraints. Global Biogeochemical Cycles. 2010;24(4):n/a-n/a. doi:10.1029/2010gb003848.

8. Rudianto. Restoration of mangrove ecosystem in coastal village based on co-management. Jurnal Perikanan Universitas Gadjah Mada. 2018;20(1):1-12.

9. Giri C, Ochieng E, Tieszen LL, Zhu Z, Singh A, Loveland T et al. Status and distribution of mangrove forests of the world using earth observation satellite data. Global Ecology and Biogeography. 2011;20(1):154-9. doi:10.1111/j.1466-8238.2010.00584.x.

10. Giesen W, Wulffraat S, Zieren M, Scholten L. Mangrove guidebook for Southeast Asia. Bangkok: FAO Regional Office for Asia and the Pacific; 2007.

11. Spalding M. World Atlas of Mangroves. Routledge; 2010.

12. Hartati, Harudu L. Identification of the types of damage to mangrove forest ecosystems due to human activities in Lowu-Lowu Village, Lea-Lea District, Baubau City. Journal of Geography Education Research. 2016;1(1):30-45. doi:10.36709/jppg.v0i0.2433.

13. Richards DR, Friess DA. Rates and drivers of mangrove deforestation in Southeast Asia, $2000-2012$. Proc Natl Acad Sci U S A. 2016;113(2):344-9. doi:10.1073/pnas.1510272113.

14. Bunting P, Rosenqvist A, Lucas R, Rebelo L-M, Hilarides $L$, Thomas $N$ et al. The Global Mangrove Watch-A New 2010 Global Baseline of Mangrove Extent. Remote Sensing. 2018;10(10). doi:10.3390/rs10101669.

15. Julkipli, Batubara RR, Jogia GE, Batubara I, Audah KA, Nunuk KN. Introduction of bioprospecting opportunities for Indonesian mangrove species. IOP Conference Series: Earth and Environmental Science. 2018;183. doi:10.1088/1755-1315/183/1/012013.

16. Rahadian A, Prasetyo LB, Setiawan Y, Wikantika K. A Historical review of data and information of Indonesian mangroves area. Media Konservasi. 2019;24(2):163-78.

17. Ilman M, Dargusch $P$, Dart $P$, Onrizal. A historical analysis of the drivers of loss and degradation of Indonesia's mangroves. Land Use Policy. 2016;54:448-59. doi:10.1016/j.landusepol.2016.03.010.

18. Silvius M, Steeman A, Berczy E, Djuharsa E, Tanfik A. The Indonesian wetland inventory: A preliminary compilation of existing information on wetlands of Indonesia. Bogor: PHPA, AWB/Interwader \& Edwin; 1987;2:I-268.

19. Burbridge PR, Koesoebiono. Management of mangrove exploitation in Indonesia. Applied Geography. 1982;2:39-54.

20. Soegiarto A, Sukardjo S. Utilization of Mangrove Forest in Brackish Water Culture Pond Development in Indonesia. In. Edited The National Workshop on Shrimp Culture. Jakarta; 1984.

21. RePPProT. The Land Resources of Indonesia: A National Overview. Jakarta: Regional Phisychal Planning Programe for Transmigration; 1990. 
22. Naamin N. Conversion of mangrove areas to tambak aquaculture in Indonesia. In. Edited Report of the Workshop on the Conversion of Mangrove Areas to Aquaculture; 1986.

23. Choong ET, Wirakusumah RS, Achmadi SS. Mangrove forset resources in Indonesia. Forest Ecology and Management. 1990;33(34):45-7.

24. BIG. Mangrove Geospatial Information of Indonesia. Jakarta: Pusat Pemetaan dan Informasi Tematik, Badan Informasi Geospasial, Indonesia; 2012.

25. KLHK. Penghitungan Deforestasi Indonesia Periode 2009-2011 (Calculation of Deforestation of Indonesia for the period of 2009-2011). Jakarta: Ministry of Forestry, Republic of Indonesia; 2012.

26. Susanto A, Subarya C, Poniman A. Kebijakan Satu Peta; Momentum Reformasi Penyelenggaraan Informasi Geospasial Nasional. In. Edited Seminar Nasional Geomatika; 2016.

27. Usmawati M. Estimation of Carbon Biomass in Mangrove Stem and Leaf Litter at Clungup Beach, Tambakrejo Village, Sumbermanjing Wetan District, Malang Regency [Thesis]. Malang: Brawijaya University; 2015.

28. Fikri MZ. Comparative Analysis of Carbon and Nitrogen Stocks in Sediments in Natural and Artificial Mangrove Forests in Lamongan Regency [Thesis]. Malang: Brawijaya University; 2017.

29. Rizky PNH. Estimation of Biomass and Carbon Stock in Live Mangrove Vegetation (Live Trees) and Surface Sediment: A Case Study of Mangrove Forest in the Bedul Resort Block, Grajagan Segoro Anak, Alas Purwo National Park (TNAP) Banyuwangi Regency, East Java Province [Essay]. Malang: Brawijaya University; 2014.

30. Aldus W. Study of Carbon Stock and Carbon Dioxide Absorption in Mangrove Ecosystems in Penunggul Village, Pasuruan Regency [Thesis]. Malang: Brawijaya University; 2017.

31. Adam BR. Estimation of Above and Below Ground Carbon Stocks and Mangrove CO2 Uptake Capacity in the Coastal Areas of Lamongan Regency [Thesis]. Malang: Brawijaya University; 2016.

32. Kauffman J, Arifanti V, Basuki I, Kurnianto S, Novita N, Murdiyarso D et al. Protocols for the measurement, monitoring, and reporting of structure, biomass, carbon stocks and greenhouse gas emissions in tropical peat swamp forests [Working Paper]. Bogor, Indonesia2016.

33. Nabuurs GJ, Masera O, Andrasko K, Benitez-Ponce P, Boer R, Dutschke M et al. Forestry. Climate Change 2007: Mitigation. Contribution of Working Group III to the Fourth Assessment Report of the Intergovernmental Panel on Climate Change, eds Metz B, et al. 2007.

34. Heriyanto N, Subiandono E. Composition and structure of stands, biomass, and potential carbon content of mangrove forests in Alas Purwo National Park. Journal of Forest Research and Nature Conservation. 2012;9(1):23-32.

35. Murray BC, Jenkins WA, Sifleet S, Pendleton L, Baldera AJ. Payments for blue carbon: potential for protecting threatened coastal habitats. 2010.

\section{Table 4}

Table 4 not available with this version 
Figures

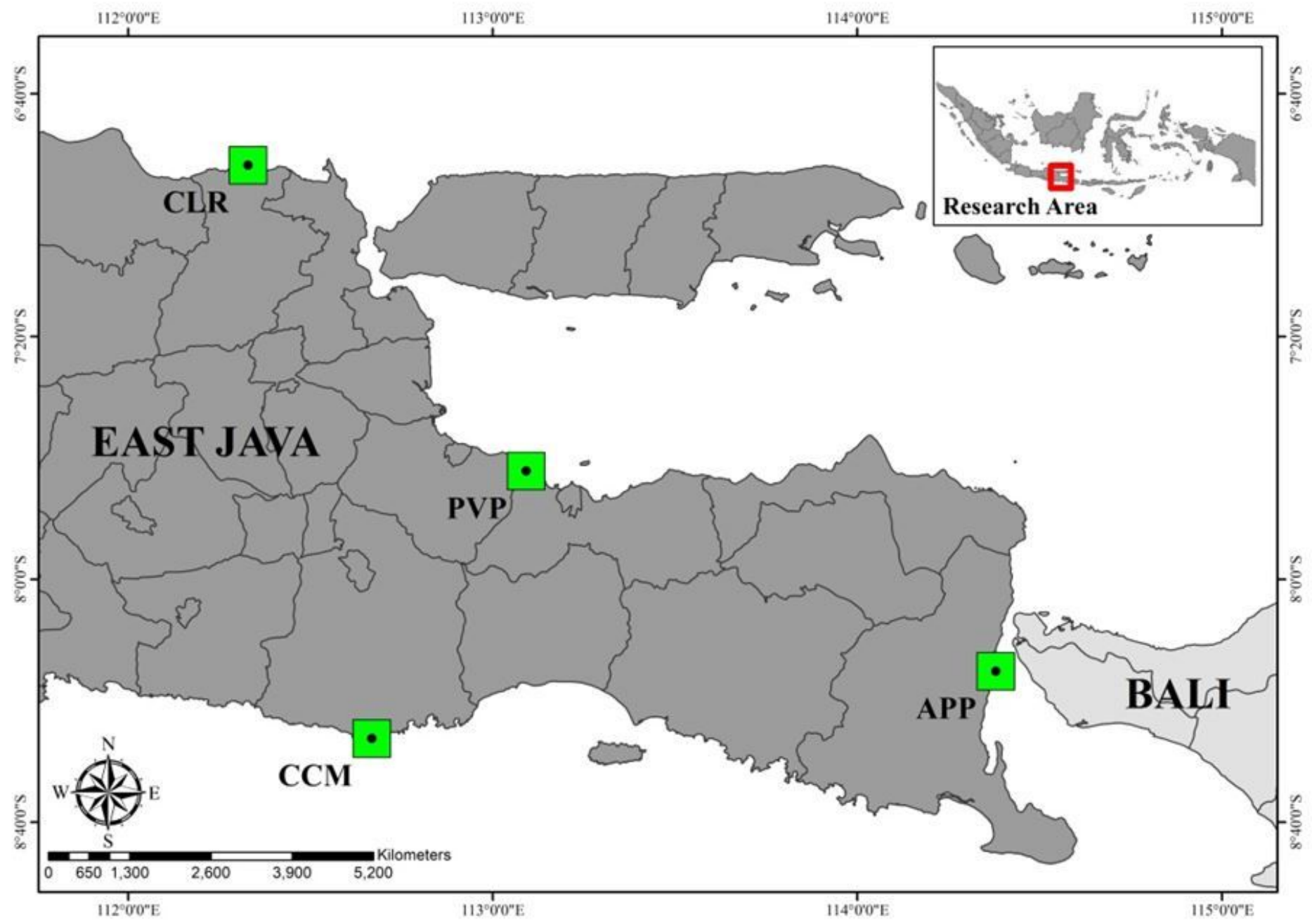

Figure 1

Location of the research area (CLR = Coastal of Lamongan Regency; PVP = Penunggal Village, Pasuruan Regency; APP = Alas Purwo National Park; and CCM = Clungup Coastal, Malang Regency) 
Goal: Irrational Use

Community utilizes mangrove forests for daily living needs (L: .165)

Community does not have awareness about the function and role of mangroves (L: .086)

Communities do not care about the destruction of mangrove forests ( $L$ : .190)

Community access to mangrove forests is easily achieved (L: .178)

Government and communities convert mangrove forests for other purposes (L: .146)

There is no supervision from the Stakeholders (L: .132)

Legal oversight is weak (L: .103)

Figure 2

Irrational use with its variables

Goal: Illegal logging

People steal mangrove wood that has a high sale value (L: .121)

Mangrove forests are increasingly reduced for residential areas (L: .248)

Declining mangrove forests are used for agriculture, plantations and animal husbandry (L: .165)

Mangrove forests are used for expansion of urban areas (L: .121)

Mangrove forests are used as road infrastructure (L: .117)

Forest fires often occur intentionally or unintentionally (L: .177)

The area of mangrove forests is increasingly reduced to be used as aquaculture (L: .051)

Figure 3

Illegal logging with its variables 
Goal: Effect of forest damage on carbon sequestration

Management of mangrove forests is not optimal (L: .206)

Absorption of mangrove forests has weakened (L: .189)

Emissions are reflected back into the air (L: .084)

Absorption above ground biomass is weak (L: .187)

Biomass in the soil is weak in absorption (L: .154)

The tree diameter is getting smaller and weak absorbtion (L: .174)

Mangrove conservation efforts are not optimal (L: .006)

Figure 4

Effect of forest damage on carbon sequestration and its variables

Goal: Law enforcement

Legal oversight is weak against illegal logging ( $L:$.289)

There are no clear legal sanctions (L: .230)

Low community involvement (L: .165)

Limited number of human resources for law enforcement (L: .316)

Figure 5

Law enforcement and its variables

Goal: Weak carbon sequestration

Mangrove area is drastically reduced (L: .162)

The conversion of mangrove land functions intensively (L: .285)

Lack of synergy between the government and the community (L: .314)

Mangrove deforestation is intensive (L: .229)

Many mangrove trees are made into charcoal by residents (L: .010)

Figure 6

Weak carbon sequestration and its variables 


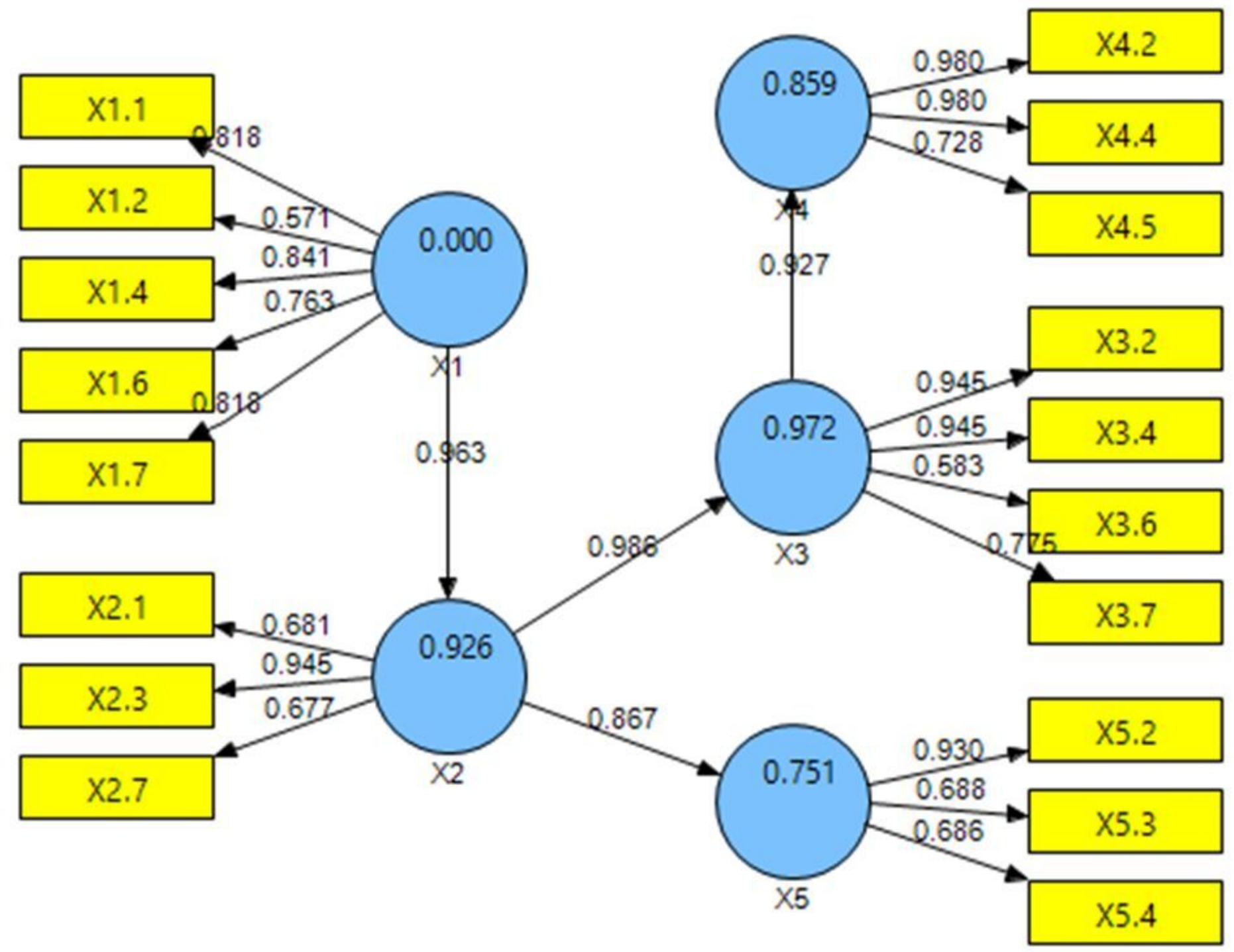

Figure 7

Structural model 